\title{
Título: CORRELAÇÃO ENTRE QUALIDADE DA ÁGUA E CASOS DE DIARREIA EM UM MUNICÍPIO DO SUL DE MINAS *
}

\author{
Autores: Claudio Avelar VALLIM; Caio Cesar Andrade Dos SANTOS; Elisa Dias De MELO
}

A qualidade da água é aspecto indispensável quando se trata dos seus principais usos e, em especial, para fins de abastecimento humano. Para o consumo humano, a água deve obedecer padrões de potabilidade que são estipulados pela Portaria 2.914 de 12 de dezembro de 2011 do Ministério da Saúde, recentemente incorporada pela Portaria de Consolidação $\mathrm{n}^{\circ} 5$, de 28 de setembro de 2017. No intuito de atender aos padrões de potabilidade algumas medidas devem ser tomadas, como a desinfecção, que constitui uma etapa do tratamento da água cuja função básica consiste na inativação dos microrganismos patogênicos. A etapa de desinfecção, introduzida no tratamento da água como complemento do processo de filtração, promoveu uma revolução tecnológica no tratamento da água. A substância mais utilizada no processo de desinfecção da água é o cloro ou produtos à base de cloro, que atuam como agentes desinfetantes. A água de consumo humano é um dos importantes veículos de enfermidades diarreicas de natureza infecciosa, o que torna primordial a avaliação de sua qualidade microbiológica. As doenças de veiculação hídrica são causadas principalmente por microrganismos patogênicos de origem entérica, animal ou humana, transmitidos basicamente pela rota fecal-oral, ou seja, são excretados nas fezes de indivíduos infectados e ingeridos na forma de água ou alimento contaminado por água poluída com fezes. O presente trabalho teve como objetivo correlacionar casos notificados de diarreia e a qualidade da água potável consumida pela população de um município localizado no sul de Minas Gerais. Foram avaliados laudos de análises de água feitas pela secretaria municipal de saúde, sendo 11 coletas por mês em pontos de consumo, de Janeiro a Dezembro no ano de 2017. Os parâmetros avaliados foram pH, turbidez, cloro residual, temperatura, coliformes totais e Escherichia coli. Dados registrados de doença diarreica aguda no Sistema de Vigilância Epidemiológica (SIVEP-DDA) foram interpretados. Como resultados, o pH ficou na média de 6,8 e o cloro residual na média mensal de $0,5 \mathrm{mg} / \mathrm{L}$, estando em conformidade com a legislação vigente, mas no limite inferior para cloro residual. Em quatro meses analisados, a turbidez passou do limite recomendado, o que representa um risco sanitário. Foi registrado 01 (um) caso positivo em Março e outro em Dezembro para coliformes totais. Foram registrados resultados negativos para E.coli em todas amostras. Durante o período, foi notificado 01 surto e 959 casos de diarreia. Para que a população receba água efetivamente potável, faz-se necessário o controle de todas as etapas do tratamento realizado nas estações de tratamento de água, uma distribuição adequada, além do armazenamento da água nos reservatórios domiciliares de forma adequada. Condições adversas no armazenamento doméstico da água podem estar relacionadas à ocorrência de casos registrados de doença diarreica aguda no município estudado.

Palavras-chave: Desinfecção, Qualidade da Água, Enfermidades diarréicas.

\section{* Apoio financeiro FAPEMIG.}

